Atıf için / For Citation: E. ERTÜRK, M. A. TEZEREN, T. TILKI, "Chiral 1,4Hydroxyarylalcohols (HAROLs) and 1,4-Aminoalkylphenols (AAPs) as Organocatalysts for Asymmetric Hetero Diels-Alder Reaction”, Süleyman Demirel Üniversitesi Fen Edebiyat Fakültesi Fen Dergisi, 14(2), 436-441, 2019.

Chiral 1,4-Hydroxyarylalcohols (HAROLs) and 1,4-Aminoalkylphenols (AAPs) as Organocatalysts for Asymmetric Hetero Diels-Alder Reaction

\author{
Erkan ERTÜRK ${ }^{* 1}$, Mustafa Ali TEZEREN ${ }^{1,2}$, Tahir TILLKİ \\ ${ }^{1}$ Institute of Chemical Technology, TÜBITTAK Marmara Research Center, 41470 Gebze, Kocaeli, Turkey \\ ${ }^{2}$ Süleyman Demirel University, Arts\&Sciences Faculty, Department of Chemistry, 32260 Isparta, Turkey \\ *corresponding authore-mail: erkan.erturk@tubitak.gov.tr
}

(Alınış / Received: 22.11.2019, Kabul / Accepted: 25.11.2019, Yaylmlanma / Published: 30.11.2019)

\begin{abstract}
In this study, two chiral 2-(2-hydroxyaryl) alcohols (HAROLs; 1,4-diols) and a 1,4aminoalkylphenol (AAP) were examined as hydrogen-bond donor (HBD) organocatalysts in the asymmetric hetero Diels-Alder (HDA) reaction of aldehydes with Rawal's diene. Catalytic amount (10 mol\%) of the both scaffolds (HAROL and AAP) have been found to effect the HDA reaction in a quite efficient manner. Among them, a HAROL molecule based on indan backbone was turned out to be the best in terms of catalytic activity and enantioselectivity. On the other hand, AAP tested seemed to act as a bifunctional organocatalyst, i.e. as both a Lewis base and HBD organocatalyst. Experimental results underpins that a careful tuning of HAROL structure might lead to the development of more general HBD organocatalysts.
\end{abstract}

Key words: Asymmetric catalysis, Hydrogen-bond donor organocatalyst, Diols, Aminoalkylphenols, Hetero Diels-Alder reaction.

\title{
Asimetrik Hetero Diels-Alder Reaksiyonu için Organaokatalizör Olarak Kiral 1,4- Hidroksiarilalkoller (HAROL) ve 1,4-Aminoalkilfenoller (AAP)
}

Özet: $\mathrm{Bu}$ çalışmada, iki tane kiral 2-(2-hidroksiaril) alkol (HAROL, 1,4-diol) ve bir 1,4aminoalkilfenol (AAP), aldehitlerin Rawal dieni ile asimetrik hetero Diels-Alder (HDA) reaksiyonunda hidrojen-bağı donörü (HBD) organokatalizörleri olarak incelenmiştir. Her iki yapının (HAROL ve AAP) katalitik miktarının (\%10) HDA reaksiyonunu oldukça verimli bir şekilde gerçekleştirdiği bulunmuştur. Bunlar arasında, indan iskeleti bazlı bir HAROL molekülünün, katalitik aktivite ve enantioseçicilik bakımından en iyisi olduğu ortaya çıkmıştır. Öte yandan, test edilen AAP bifonksiyonlu bir organokatalizör olarak, diğer bir deyişle bir Lewis bazı ve HBD organokatalizörü gibi davranıyor görünmektedir. Deneysel sonuçlar HAROL yapısının dikkatli bir şekilde ayarlanmasının, daha genel HBD organokatalizörlerinin geliştirilmesine yol açabileceğini desteklemektedir.

Anahtar kelimeler: Asimetrik kataliz, Hidrojen bağı sağlayıcı organokatalizör, Dioller, Aminoalkilfenoller, Hetero Diels-Alder reaksiyonu

\section{Introduction}

The hetero Diels-Alder (HDA) reaction is a reaction between carbonyl or imine compounds and dienes allowing an easy access to corresponding chiral pyran or piperidine derivatives [1]. It is mostly needed to be catalyzed by a Lewis acid if the diene component is not electron-rich enough. Therefore, a rather large number of chiral metal complexes have been developed as Lewis acid catalysts for asymmetric version of 
HDA reaction in recent years [2, 3]. On the other hand, small organic molecules as catalysts (organocatalysts) have recently been demonstrated not only to be highly effective as metal-based ones, but also to exhibit unique activation modes, thereby offering new opportunities in synthesis. Thus, asymmetric organocatalysis has become an area of intense research [4]. These efforts have culminated in identification of certain organic functional groups for accelerating some organic transformations by forming hydrogen bond with acceptors, in a very similar manner to metal-based Lewis acid catalysts [5]. Among them, (thio)ureas, squaramides, and diols are most broadly known hydrogen-bond donor (HBD) organocatalysts (Figure 1). Diols (4), e.g. TADDOL, BINOL, and their derivatives, generally are capable of forming one intramolecular and one intermolecular hydrogen bond, while (thio)ureas (1 and 2) and squaramides (3) are characteristically able to donate two H-bonds to an acceptor [5-7].
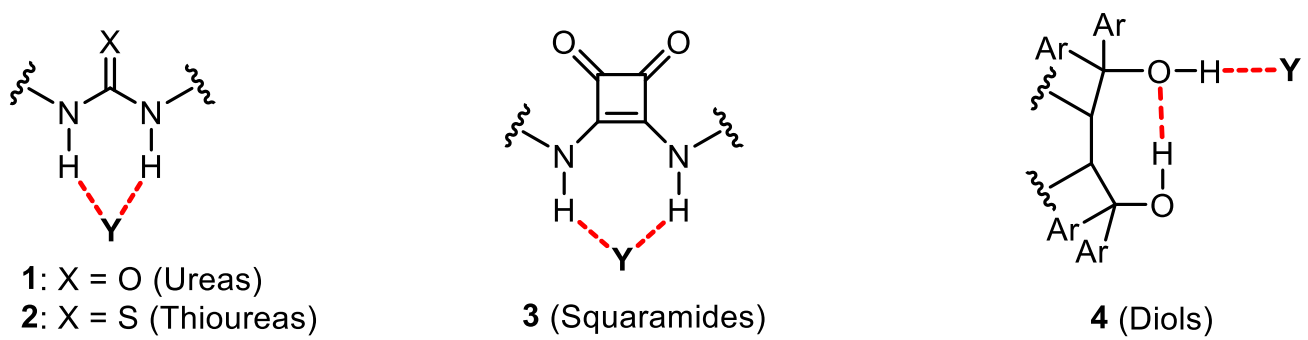

Figure 1. Typical hydrogen-bond donor (HBD) motifs ( $\mathrm{Y}=\mathrm{H}-$ bond acceptor).

In 2003, Rawal and co-workers achieved enantioselective HDA reaction between aldehydes (9) and Rawal's diene (8) by using TADDOLs ( $\alpha, \alpha, \alpha^{\prime}, \alpha^{\prime}$-tetraaryl- 2,2dimethyl-1,3-dioxolane-4,5-dimethanol, a diol) as the HBD organocatalysts [8]. This reaction was later improved in terms of yield and enantioselectivity by introducing an axially chiral organocatalyst BAMOL (1,1'-biaryl-2,2'-dimethanol, a diol), thus reporting up to $96 \%$ yield and $>99 \%$ ee [9]. Later on, TADDOL derivatives were also proven to be effective in HDA reaction of aldehydes with Brassard'd diene as well as Danishefsky's diene, though yields and enantioslectivities were mediocre $[10,11]$. Bolm and co-workers reported that planar-chiral bis-silanols and diols are able to catalyze HDA between aldehydes and Rawal's diene, with low activity and enantioselectivity [12]. Very recently, Guiry and co-workers introduced ferrocenyl diols as organocatalysts possessing both axial and central chiralities in asymmetric HDA reaction of aldehydes with Rawal's diene [13]. It should also be mentioned that Itoh and co-workers reported that a chiral phenol bearing a sulfonamide fuctionality derived from the Betti base can catalyze the HDA reaction of ethyl glyoxylate with Danishefsky's diene with high activity and modest enantioselectivities [14]. At this point, it should be noted that in 1985 Hine and co-workers already disclosed a nonasymmetric ring-opening reaction of phenyl glycidyl ether with diethylamine in the presence of 1,8-biphenylenediol as the catalyst [15]. Afterwards, there have also appeared other works in which phenols were used as HBD organocatalyst in particular cases $[16,17]$.

We recently developed chiral 2-(2-hydroxyaryl)alcohols (HAROLs) and 2-(2aminoalkyl)phenols (AAPs) as organocatalysts for the enantioselective Morita-BaylisHillman reaction and aldol reaction, respectively (Figure 2) [18-20]. AAPs were also found to accelerate enantioselective diethylzinc addition reaction to benzaldehyde in high yields and enantioselectivities [21]. In connection with those works, we reasoned that our HAROLs could catalyze HDA reaction of aldehydes with Rawal's diene, in a 
similar way to the diol organocatalysts discussed above. Furthermore, our AAPs could be effective in the same transformation as a bifunctional organocatalyst. The amine functionality of AAPs could activate the silyl group of Rawal's diene, while phenolic hydroxyl group would build hydrogen bonding with carbonyl group of the respective aldehyde. Herein, we would like to report that HAROLs and AAPs can catalyze the HDA reaction of aldehydes with Rawal's diene.

HAROL<smiles>[R]Cc1cc([R])cc(OCCO)c1[R]</smiles>

intramolecular hydrogen bond
$A A P$<smiles>[R][R]1ccc(CN([R])[R])c(O)c1[R]</smiles>

Lewis- or Lewis- or

Brønsted-acid Brønsted-base

Figure 2. Activation modes envisinoed for HAROLs and AAPs as organocatalysts.

\section{Material and Method}

Preparation of HAROLs (5 and 6, Figure 3) was described in our previous work [19]. The protected form of $(S)$-2-(3,5-di-tert-butyl-2-hydroxyphenyl)-1-phenylethanol (5) could be obtained in a one-pot synthesis strategy through the ring-opening of $(R)$ styrene oxide with the corresponding lithioanisole [18]. On the other hand, the HAROL 6 could be obtained through the palladium-catalyzed $\alpha$-arylation of indan-1-one with the respective ortho-bromoanisole, enantioselective reduction of the formed ketone, and demethylation, in order [19]. It should be pointed out that the HAROLs selected for screening are structurally somewhat different from each other. The HAROL $\mathbf{5}$ has a linear scaffold, whereas the HAROL 6 is based on the cyclic indan backbone (Figure 3). A straightforward synthesis of the AAP 7 was also published in our previous work, which involves Mitsunobu reaction, Eschweiler-Clarke $N$-methylation, as well as demethylation of the respective anisole intermediate [21].<smiles>CC(C)(C)c1cc(CC(O)c2ccccc2)c(O)c(C(C)(C)C)c1</smiles>

5

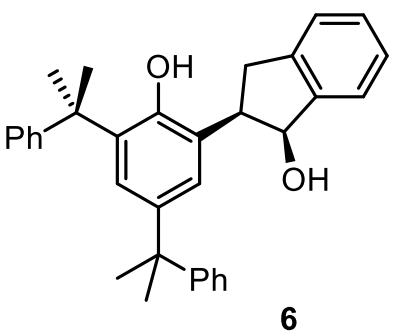

6<smiles>CN(C)[C@@H](Cc1cc(C(C)(C)C)cc(C(C)(C)C)c1O)c1ccccc1</smiles>

Figure 3. HAROLs (5 and 6) and AAP 7 studied in HDA reaction.

\subsection{Experimental section}

General procedure for catalytic trials (asymmetric hetero Diels-Alder reaction): An oven dried $10 \mathrm{~mL}$ schlenk tube equipped with a magnetic stir bar was charged with catalyst $(10 \mathrm{~mol} \%)$ and capped with a glass stopper. The tube was evacuated for $15 \mathrm{~min}$ and back-filled with dry nitrogen and the glass stopper was replaced with a rubber septum. Dry dichloromethane $(2 \mathrm{~mL}$ for $1.0 \mathrm{mmol}$ of $\mathbf{8}$ ) was supplied into the tube by using a gas-tight syringe. Then, the aldehyde (9a or 9b, 2.00 equiv) was drop-wise added into the tube. The reaction mixture was cooled to $-40{ }^{\circ} \mathrm{C}$ by means of a cooling 
bath. Then, (E)-1-dimethylamino-3-tert-butyldimethylsiloxy-1,3-butadiene $(\mathbf{8}, \quad 1.00$ equiv) was drop by drop transferred into the tube at this temperature. The reaction mixture was stirred at $-40{ }^{\circ} \mathrm{C}$ for $48 \mathrm{~h}$ and then cooled to $-78^{\circ} \mathrm{C}$. The reaction mixture was quenched by the addition of acetyl chloride (2.00 eq) and stirred for a further 15 min. The product was directly isolated by column chromatographic separation on silica gel (hexanes/EtOAc, 8:2).

(S)-2,3-Dihydro-2-phenyl-4H-pyran-4-one (11a): The product was isolated as a clear colorless oil. The absolute configuration of the enantiomer formed in excess was determined by comparing the retention times with the literature HPLC data performed under the same conditions [9]. TLC: $R_{\mathrm{f}}=0.28$ (silica gel; hexanes/EtOAc, 8:2). FTIR $(\mathrm{KBr}): v_{\max }\left(\mathrm{cm}^{-1}\right)=3448(\mathrm{~m}), 2915(\mathrm{w}), 1671(\mathrm{C}=\mathrm{O} ; \mathrm{s}), 1595(\mathrm{~s}), 1452(\mathrm{~m}), 1404(\mathrm{~m})$, 1270 (m), 1222 (s), 1219 (m), 1059 (s), 939 (m), 769(s), 698 (w). ${ }^{1} \mathrm{H}$ NMR (500 MHz, $\left.\mathrm{CDCl}_{3}\right): \delta=7.48(\mathrm{dd}, J=6.0,0.6 \mathrm{~Hz}, 1 \mathrm{H}), 7.45-7.36(\mathrm{~m}, 5 \mathrm{H}), 5.52(\mathrm{dd}, J=6.0,1.3$ $\mathrm{Hz}, 1 \mathrm{H}), 5.43(\mathrm{dd}, J=14.4,3.4 \mathrm{~Hz}, 1 \mathrm{H}), 2.91(\mathrm{dd}, J=16.9,14.4 \mathrm{~Hz}, 1 \mathrm{H}), 2.66$ (ddd, $J$ $=16.9,3.5,1.3 \mathrm{~Hz}, 1 \mathrm{H}) .{ }^{13} \mathrm{C} \mathrm{NMR}\left(\mathrm{APT}, 125 \mathrm{MHz}, \mathrm{CDCl}_{3}\right): \delta=192.1(\mathrm{C}), 163.4(\mathrm{CH})$, $137.9(\mathrm{C}), 129.0(\mathrm{CH}), 128.9(\mathrm{CH}), 126.1(\mathrm{CH}), 107.4(\mathrm{CH}), 126.7(\mathrm{C}), 81.1(\mathrm{CH}), 43.4$ $\left(\mathrm{CH}_{2}\right)$. HPLC: Daicel Chiralpak OD-H (4.60 mm ID $\times 250 \mathrm{~mm}$ column length); $n$ hexane $/ i-\mathrm{PrOH}(90: 10), 1 \mathrm{~mL} / \mathrm{min} ; 220 \mathrm{~nm}(\mathrm{UV}-\mathrm{vis}) ; t_{\mathrm{R}}=13.5 \mathrm{~min}(\mathbf{1 1 a}), t_{\mathrm{R}}=16.1 \mathrm{~min}$ (ent-11a).

\section{Results}

The catalyst candidates $(\mathbf{5}, \mathbf{6}$, and $\mathbf{7})$ selected from our library were examined in the HDA reaction in order to determine their HBD abilities. As a proof of concept, the HDA reactions of benzaldehyde (9a) and 3-phenylpropionaldehyde (9b) with Rawal's diene (8) were investigated (Table 1). Initially, the catalytic activity of HAROLs and the AAP 7 were screened under neat conditions, by loading of $10 \mathrm{~mol} \%$ catalyst (entries $1-$ $3)$. HAROL 6 exhibited moderate catalytic activity and a slight enantioselectivity (entry 2), whereas HAROL 5 had not any effect on the reaction (entry 1). On the other hand, the employment of the AAP 7 revealed that it had only a noticeable catalytic activity in the HDA reaction between 9a and $\mathbf{8}$ (entry 3). Interestingly, the use of toluene as the solvent deleted the enantioselectivity of HAROL $\mathbf{6}$ on the reaction, whereas it was the solvent of choice that exhibited the highest activity according to Rawal's group studies (entry 4). However, toluene was not deleterious on the enantioselectivity of the HAROL 6 when 3-phenylpropionaldehyde (9b) was used as the aldehyde (entry 5). To probe these organocatalysts further, we examined the effect of solvent and temperature variations on both the yield and the enantioselectivity of the cycloaddition. The results showed that changing the solvent from toluene to dichloromethane made some increase in catalytic activity, whereas the enantiopurity of the cycloadduct was not affected (entry 6). On the other hand, decrease in the reaction temperature from $-40{ }^{\circ} \mathrm{C}$ to -78 ${ }^{\circ} \mathrm{C}$ resulted in retardation of the reaction (entry 7 ). 
Table 1. Investigation of Asymmetric Hetero Diels-Alder Reaction Catalyzed by HAROLs and AAP. ${ }^{[a]}$

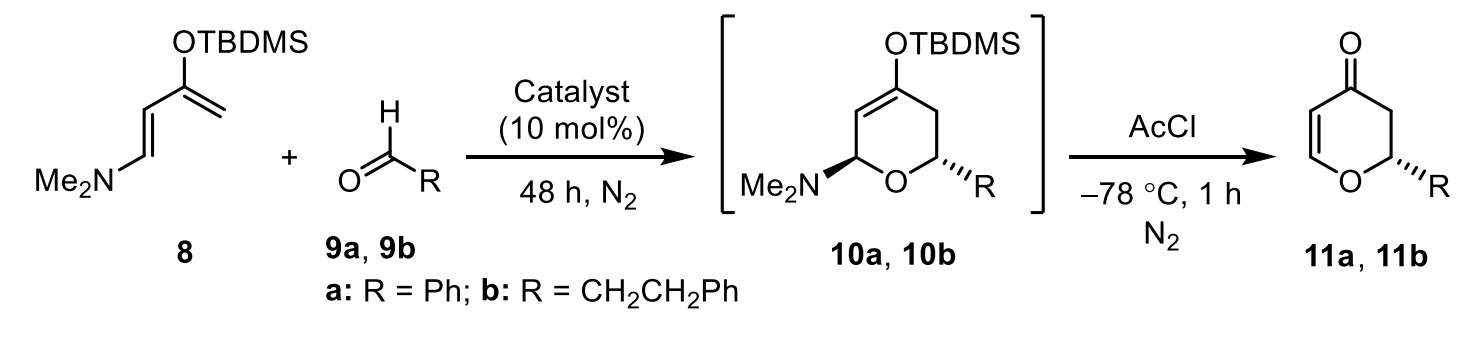

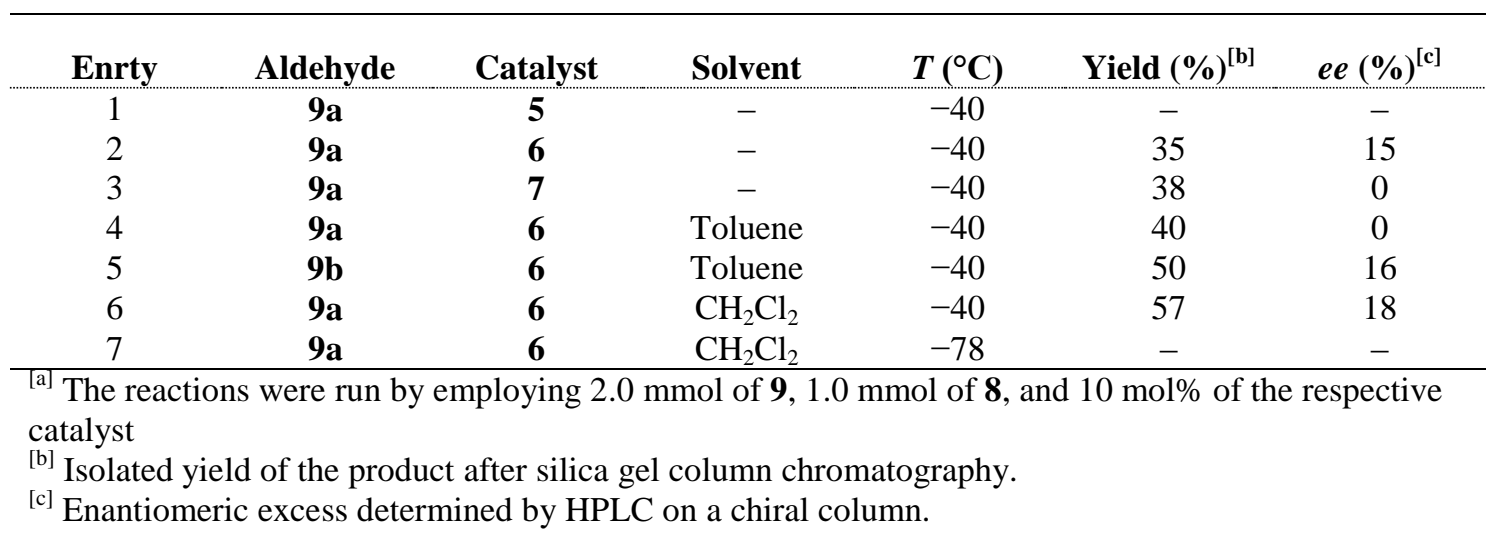

\section{Conclusion and Comment}

In summary, we have examined the intermolecular hydrogen bonding activation of aldehydes with HAROL and AAP frameworks in the asymmetric HDA reaction of aldehydes with Rawal's diene. Among the catalyst tested, the HAROL 6 based on indan skeleton was proven to be best in terms of both enantioselectivity and catalytic activity. However, the results obtained during the course of these studies are not competitive compared with the most widely used organocatalyst scaffolds. On the other hand, the development of a new and efficient single $\mathrm{H}$-bond donor is generally a challenging concept due to difficulties in providing a rigid catalyst-substrate interaction when compared to double $\mathrm{H}$-bond donor catalysts. It was also important to observe that the HAROL $\mathbf{6}$ in comparison to the HAROL $\mathbf{5}$ have a significant impact on reactivity and stereoselectivity. This result shows that the modification around the HAROL scaffold to achieve more effective steric and electronic characteristics could render a rigid and stronger intermolecular H-bond formation with carbonyl groups. Consequently, this study could be seen as the first baby steps to lead to a new direction of exploration.

\section{Acknowledgments}

We would like to thank both the Scientific and Technological Research Council of Turkey (grant no. 111T597) and Süleyman Demirel University (BAP project no. 4072D1-14) for their financial supports.

\section{References}

[1] K. A. Jorgensen, "Catalytic asymmetric hetero-Diels-Alder reactions of carbonyl compounds and imines,” Angew. Chem. Int. Ed., 39, 3558-3588, 2000.

[2] H. Pellissier, "Asymmetric hetero-Diels-Alder reactions of carbonyl compounds," Tetrahedron, 65, 2839-2877, 2009.

[3] G. Blond, M. Gulea, and V. Mamane, "Recent contributions to hetero Diels-Alder reactions," Curr. Org. Chem., 20, 2161-2210, 2016.

[4] A. Berkessel and H. Gröger, Asymmetric Organocatalysis. Weinheim: Wiley-VCH, 2005. 
[5] M. S. Taylor and E. N. Jacobsen, "Asymmetric catalysis by chiral hydrogen-bond donors," Angew. Chem. Int. Ed., 45, 1520-1543, 2006.

[6] T. N. Nguyen, P.-A. Chen, K. Setthakarn, and J. A. May, "Chiral diol-based organocatalysts in enantioselective reactions," Molecules, 23, 2317-2353, 2018.

[7] A. Berkessel, S. S. Vormittag, N. E. Schlörer, and J.-M. Neudörfl, "TEFDDOLs $\left(\alpha, \alpha, \alpha^{\prime}, \alpha^{\prime}-\right.$ tetrakis(perfluoroaryl/alkyl)-2,2'-dimethyl-1,3-dioxolane-4,5-dimethanols): Highly fluorinated chiral $\mathrm{H}$-bond donors and Brønsted acids with distinct $\mathrm{H}$-bonding patterns and supramolecular architectures," J. Org. Chem., 77, 10145-10157, 2012.

[8] V. H. Rawal, A. N. Thadani, A. K. Unni, and Y. Huang, "Single enantiomers from a chiral-alcohol catalyst," Nature, 424, 146, 2003.

[9] A. K. Unni, N. Takenaka, H. Yamamoto, and V. H. Rawal, "Axially chiral biaryl diols catalyze highly enantioselective hetero-Diels-Alder reactions through hydrogen bonding," J. Am. Chem. Soc., 127, 1336-1337, 2005.

[10] H. Du, D. Zhao, and K. Ding, "Enantioselective catalysis of the hetero-Diels-Alder reaction between Brassard's diene and aldehydes by hydrogen-bonding activation: A one-step synthesis of $(S)-(+)$ dihydrokawain," Chem. Eur. J., 10, 5964-5970, 2004.

[11] X. Zhang, H. Du, Z. Wang, Y.-D. Wu, and K. Ding, "Experimental and theoretical studies on the hydrogen-bond-promoted enantioselective hetero-Diels-Alder reaction of Danishefsky's diene with benzaldehyde," J. Org. Chem., 71, 2862-2869, 2006.

[12] C. Beemelmanns, R. Husmann, D. K. Whelligan, S. Özçubukçu, and C. Bolm, "Planar-chiral bissilanols and diols as H-bonding asymmetric organocatalysts," Eur. J. Org. Chem., 3373-3376, 2012.

[13] C. Nottingham, H. Müller-Bunz, and P. J. Guiry, "A family of chiral ferrocenyl diols: Modular synthesis, solid-state characterization, and application in asymmetric organocatalysis," Angew. Chem. Int. Ed., 55, 11115-11119, 2016.

[14] T. Kanemitsu, Y. Asajima, T. Shibata, M. Miyazaki, K. Nagata, and T. Itoh, "Novel sulfonamide catalyzed asymmetric hetero Diels-Alder reaction of ethyl glyoxylate with Danishefsky's diene," Heterocycles, 83, 2525-2534, 2011.

[15] J. Hine, S.-M. Linden, and V. M. Kanagasabapathy, "1,8-Biphenylenediol is a double-hydrogenbonding catalyst for reaction of an epoxide with a nucleophile," J. Am. Chem. Soc., 107, 1082-1083, 1985.

[16] Y. E. Türkmen and V. H. Rawal, "Exploring the potential of diarylacetylenediols as hydrogen bonding catalysts," J. Org. Chem., 78, 8340-8353, 2013.

[17] P. Chauhan and S. S. Chimni, "Aromatic hydroxyl group - a hydrogen bonding activator in bifunctional asymmetric organocatalysis," RSC Adv., 2, 737-758, 2012.

[18] E. Ertürk, M. A. Tezeren, T. Atalar, and T. Tilki, "Regioselective ring-opening of epoxides with ortho-lithioanisoles catalyzed by $\mathrm{BF}_{3} \cdot \mathrm{OEt}_{2}$," Tetrahedron, 68, 6463-6471, 2012.

[19] Ö. Dilek, M. A. Tezeren, T. Tilki, and E. Ertürk, "Chiral 2-(2-hydroxyaryl)alcohols (HAROLs) with a 1,4-diol ccaffold as a new family of ligands and organocatalysts," Tetrahedron, 74, 268-286, 2018.

[20] M. A. Tezeren, T. A. Yeşil, Y. Zorlu, T. Tilki, and E. Ertürk, "Enantiopure cis-and trans-2-(2aminocyclohexyl)phenols: Effective preparation, solid-state characterization, and application in asymmetric organocatalysis," Eur. J. Org. Chem., 7017-7032, 2018.

[21] Ö. Dilek, M. A. Tezeren, T. Tilki, and E. Ertürk, "Chiral 1,4-aminoalkylphenols for enantioselective diethylzinc addition to aldehydes,” Turk. J. Chem., 43, 612-623, 2019. 